\author{
Jelena Seferović \\ University of Ljubljana, Faculty of Arts, Aškerčeva cesta 2, SI-1000 Ljubljana \\ jelenaseferovic@yahoo.com
}

\title{
Reflection on the (Un)Power of Men in the Context of Post-war Everyday Life of Croatian War Veterans with Mental Disorders from World War I
}

\begin{abstract}
This paper discusses the resocialisation of the Croatian war veterans with mental disorders from World War I. It is based on an analysis of the psychiatric patient files of soldiers who were treated in two Croatian psychiatric hospitals from 1919 to 1924. Their process of social reintegration into the community after return from the battlefield is considered concerning their (in)ability to realise normative expectations regarding the gender role of men. The intention was to research whether this circumstance in part contributed to the development of feelings of powerlessness in the latter stage and consequently caused their antisocial behaviour as a result of which they were socially excluded from their home community.
\end{abstract}

\section{Keywords}

World War I, war veterans, mental disorder, resocialisation, male gender roles, powerlessness, history of psychiatry

\section{Introduction}

This paper ${ }^{1}$ discusses the post-war everyday life of Croatian war veterans with mental disorders treated from 1919 to 1924 in two psychiatric hospitals in Croatia. Those institutions were the hospital "Stenjevec" located in the suburbs of Zagreb and the psychiatric ward of the General Hospital in Pakrac. The population included in this study were soldiers who began to show clear signs of mental illness during the war or after returning from the battlefield. Since the topic is approached from the perspective of sociocultural anthropology, the paper will not consider whether and to what extent their war traumatic experiences contributed to the development of their mental illness. The focus is on the analysis of the process of resocialisation of soldiers with mental disorders in rural areas of the continental part of Croatia in the postwar period. War veterans originating from villages in continental Croatia were taken into account because no cases of those coming from other Croatian regions were encountered. The archival research of the patient files of the latter's was conducted in the Archives of the Clinic for Psychiatry "Vrapče", formerly "Stenjevec", and in the Museum of Pakrac. The article presents a few representative examples that stood out from many similar cases collected in the analysed archival documentation.

The report is based on the archival research conducted as part of the project "Post-war transitions in gendered perspective: The case of the North-Eastern Adriatic region". The project was funded by the European
Research Council under the Horizon 2020 program - ERC Grant Agreement n. 742683. For additional information see: https://project-eirene.eu/ (accessed on 24 May 2020). 
The first part presents specific details related to the history of the origin and development of "Stenjevec" and "Pakrac" and the organisation of everyday life of patients hospitalised in these two hospitals. The daily routine of patients in both institutions is considered concerning the content of activities organised as part of occupational therapy and their (in)ability to engage in them. Special interest is given to the analysis of the consequences of the spatial dislocation of the researched psychiatric institutions and the social (self) exclusion of war veterans with mental disorders on their reintegration into the community after returning from the war.

The second part analyses the consequences of limitations of the provision of psychiatric assistance and social support to war veterans with mental disorders on their active involvement in post-war everyday life. On the one hand, the reason why they could not be provided with adequate psychiatric treatment and the preconditions for reintegration into the community was insufficient knowledge regarding the nature of their mental illness by professionals. On the other hand, the cause of social (self)exclusion of the studied population was a lack of understanding and lack of empathy of the home environment for their mental illness.

The article ends with a chapter that deals with changes in the family dynamics of soldiers with mental disorders that occurred after their return from the battlefield. First, it discusses various forms of domestic violence of the latter, which are presumed to have been partly conditioned by their inability to meet the traditional expectations intended for men. Patriarchal societies expect men to be dominant, sexually active, able to work and nourish their families, but soldiers who returned traumatised from the war were not empowered to realise these social demands. It is probable that, in addition to the symptoms of mental illness, the loss of their previous positions of power within the family and the community made them powerless. Because of this frustration, they acted (auto)destructively. Secondly, the third chapter discusses the consequences of the absence of soldiers in the process of raising children during the war. Pointed out is that the lack of their contribution to the upbringing of children harmed the socialisation of the latter. Therefore, it is recommended for further research to pay special attention to the upbringing of children of deceased and missing soldiers in the WWI, as well as the transgenerational transmission of trauma from war veterans with mental disorders to their children.

The essential contribution of this paper is the presentation and analysis of the post-war everyday life of Croatian war veterans with mental disorders from WWI through the prism of their own experiences recorded in medical documentation, which have not been taken into account in previous Croatian research of this topic. The findings gained in this research can also serve as a contribution to the historical and anthropological consideration of changes related to the structure and relationships within rural families in continental Croatia after WWI.

\section{Some Aspects of the Organization of Everyday Life in Psychiatric Hospitals}

The establishment of psychiatric hospitals "Stenjevec" and "Pakrac" dates from the Austro-Hungarian period. The first, "Stenjevec", known today as the University Psychiatric Hospital Vrapče, was opened in 1879. Negotiations 
on the construction of the hospital have been ongoing since the end of 1877 because the location on which the institution would be built was disputed.

The initial idea was to establish it in the very centre of Zagreb, in Ilica. Finally, the government purchased land from the Kaptol, ${ }^{2}$ in the outskirts of the city, the municipality of Vrapče. Initially, it was supposed to accommodate 200 patients, but as the planned capacity was soon significantly exceeded (Herceg 1933: 6-8), Pakrac General Hospital hospital opened a psychiatric department in 1910, in a nearby building that was built explicitly for this purpose (Herman Kaurić 2014: 200-201). ${ }^{3}$ Judging by the use of the term odiel (ward), printed in the headline of Pakrac's patient files, it could be hardly concluded that it was a construction of larger dimensions intended for the reception of about 200 peaceful psychiatric patients. ${ }^{4}$

Psychiatric hospitals "Stenjevec" and "Pakrac" were "health resorts in the true sense of the word", but at the same time they were intended as a form of "nursing homes for already chronic patients as well as (...) idiots and epileptics" and therefore sometimes cared for "older cases and over twenty years". Both institutions were spatially located in relation to densely populated areas, which is why they carried "the characteristic of some loneliness, desert and inaccessibility"s (Lopašić 1924: 71). Patients were allocated to wards according to the degree of symptoms of mental disorders, physical immobility and (in)ability to control physiological needs. For this reason, wards were arranged for healing, on the one hand, "calm" or "restless", while on the other, those "unclean" who had a problem in holding their urine or stool. According to some psychiatrist, that loss of personal freedom and autonomy implies a loss of power. In a word, "the destructive power of agoraphobia lies

2

Kaptol is the seat of the Roman Catholic Archdiocese of Zagreb.

3

Previously there was a small psychiatric ward on the ground floor of a general hospital, but it was under capacity. This was also one of the reasons why it was necessary to open a ward to accommodate more psychiatric patients (Herman Kaurić 2014: 200).

4

The only statistical data on the number of patients treated at "Stenjevec" in the period covered by this study indicates that 511 people were hospitalized in 1919. The number of patient files from 1919 stored in the Archives of the University Psychiatric Hospital Vrapče did not correspond to this calculation recorded in the monograph of this hospital that dates from 1933. It was thus far not possible to find in archival material nor in the available professional literature the statistics on the admissions of patients to psychiatric ward in "Pakrac". Judging by the number of found male psychiatric patient files in both hospitals, it could be estimated that from 1919 to 1924 , there were between 70 and 100 per year on placement. However, this estimate cannot be relevant because, as mentioned at the outset, there is a discrepancy in the number of patient files collected in this research in the relation to the statistics on the number of patients treated in the "Stenjevec" recorded in its monograph from 1933. In addition, all medical records from "Pakrac" were not stored in the Museum in Pakrac.

\section{5}

One of the basic forms of collaboration among these two hospitals, as far as we know, has been patient exchange. Specifically, patients from "Stenjevec" were transferred to "Pakrac" because of its under capacity. They were "transported" in groups, starting in late spring and early autumn. Travel time was conditioned by rare rail lines, weather (in) conditions, and the fact that patients required an escort of paramedics on their way to $\mathrm{Pa}$ krac. Because of that, there would be a shortage of paramedics in "Stenjevec" for several days, which made the organization of work in the wards even more difficult - there were too few hospital staff in the hospital in general. The deficit of health professionals in these institutions was also reflected in the lack of psychiatrists. For example, in 1923, 640 patients were hospitalized at "Stenjevec", while the number of doctors, including the director, was 7. In particular, 760 patients and 5 psychiatrists were recorded (Lopašić 1924: 73). 
in the inability of the patient to take possession of space as a personal world in which he can reside and through which he can move" (Pelegrina 2004: 87). Separation of psychiatric patients from the majority of community into dislocated institutions, due to their inability to maintain social contact and spatial reintegration, can only result in deepening their segregation and negative stereotyping. Spatially approaching psychiatric hospitals to the rest of the population could potentially mitigate prejudices and generalisations related to people with mental disabilities, which could encourage their better social interaction with the environment (cf. Rossler 2016: 1250).

In his article from 1924 "The position of a mental health doctor", Croatian psychiatrist Radoslav Lopašić discusses five specific problems of the psychiatric system of that time. Referring to the structure of psychiatric patients, he points out that "in addition to patients who cannot cope for psychical or organic reasons, we have patients who are just characterised by their exuberant vivacity". The author explains that "these are especially catatonic people and epileptics in our country, who are unusually dangerous for their environment, and who stand out for their horrible, ruthless, vicious, and bloodthirsty aggression" (Lopašić 1924: 71).

In the previous descriptions of the spatial dislocation of psychiatric hospitals, as well as in the presentation of the strategy of grouping their patients, recognisable are similarities with the elements of the concept of spatial segregation. According to Pierre Bourdieu's theory of social and appropriated physical space, "the physical proximity of socially distant persons is usually perceived as unbearable and therefore results in the spatial separation of socially distant persons" (Bourdieu according to Kuti, Gregurović, Božić 2011: 328). Bourdieu's thesis somewhat explains the inability of the dominant society to give way to psychiatric patients within its physical and social space.

The most significant aspect of everyday life in "Stenjevec" and "Pakrac" was occupational therapy. In psychiatry, occupational therapy began in the 1920s, and as far it is known, and German psychiatrist Hermann Simon was its pioneer. According to Simon, the goal of engaging patients during hospitalisation in some form of organised activities, especially physical ones, was to strengthen their confidence and self-discipline. But he did not hide his bias towards more efficient patients. He classified those who did not show the desired results in terms of productivity and the speed of realisation of their assigned obligations as part of occupational therapy as social parasites. The reason for this attitude lies in the fact that Simon based his ideology on the principles of eugenics (Rissanen 2018: 197; Roelcke 2005: 167).

A decade later, elaborating on occupational therapy at "Stenjevec", Croatian psychiatrist Bernard Berglas stated that "a healthy person strives for employment because the force that is created in our body during the life process seeks to be released". He emphasised that, like healthy people, "mental patients also have a need for employment, except that because of the disruption of the mental component, which is primarily required for work, this release of power does not drain in one specific and productive direction, but is manifested in some senseless movements, arousal, and other similar asocial phenomena" (Berglas 1933: 122). Discussing the question of the "will to meaning", Austrian neurologist and psychiatrist Viktor E. Frankl warned that the search for the sense of meaning in our life is a crucial need of every human being. In his opinion "being human means being in the face of meaning to fulfil and values to realise" (Frankl 2014). Although not all psychiatric patients were 
productive to the extent that, for example, Hermann Simon and his followers expected, it was necessary to fulfil and make sense of their daily routine. It seems that one of the goals of occupational therapy was to try to provide a sense of existence to patients through work. However, this humane idea has been interpreted in different ways in certain psychiatric institutions, and some psychiatrist and hospital staff abused their position at the expense of patients. The content and number of activities planned as part of occupational therapy differed in the two hospitals under study. "Stenjevec" had a large number of craft workshops unmentioned in the medical records of patients from "Pakrac", in particular, carpentry, tailoring and upholstery workshops. Further, in 1922 "Stenjevec" purchased land from "Jankomir", a gardening and seed-growing company, on which the hospital economy was founded (Herceg 1933: 17). According to the results of this research, the patients in both hospitals were war veterans, and more generally men, mostly farmers, from rural parts of central and eastern Croatia. ${ }^{6}$ Their age ranged between the early twenties and early forties. Given that they had been already previously qualified for agricultural jobs during psychiatric treatments, most of them were involved in working on hospital economies. ${ }^{7}$ All new patients, if they were capable of working, were referred to work immediately after admission. A good example to illustrate this is the case of a sixty-six-year-old patient who came in 1915 accompanied by a paramedic from "Stenjevec" to "Pakrac". He was a farmer from a village in continental Croatia. It is known that he had been married and had children. After four years of his hospitalisation in "Pakrac" he died of tuberculosis of the lungs. ${ }^{8}$ He was diagnosed with dementia secundaria until his death in 1919.

"The patient was immediately after he was admitted to the hospital sent to work with other patients and worked in a garden and hospital field." (Male patient files, Pakrac, June 1919)

However, not all patients were psychophysically fit to participate in hospital economics and craft workshops. While some of them spent time in the hospital in executing tasks within occupational therapy, others were almost com-

The cases of Dalmatian soldiers treated in "Stenjevec" and "Pakrac" were extremely rare. A possible reason for this could be that only one division of the Austro-Hungarian army was formed in this region, so they were generally less represented than soldiers from continental Croatia. The contribution of Dalmatians in the First World War was mostly reflected in their participation in one of the Navy Corps (Pavičić 1998: 247-249). Furthermore, the "Provincial Madhouse" was opened in 1883 as part of the Šibenik General Hospital, which was primarily used to house patients from Dalmatia. Therefore, it is very likely that soldiers with mental disorders from this region were most often hospitalized in this psychiatric hospital (Rašković 1983: 163).

7

The remaining patients, though rare, were butchers, shoemakers, masons and blacksmiths. They could find jobs in "Stenjevec" because, as already mentioned, the hospital had numerous craft workshops. There were an insignificant number of merchants, clerks or teachers and members of other categories of intellectuals among psychiatric patients. This does not mean that the latter group did not suffer from psychiatric disorders, but that they were less hospitalized in psychiatric hospitals here. It is assumed they were sent for psychiatric treatments outside the homeland with the aim of avoiding stigmatization and shaming of their families. Hospitalizations abroad for farmers were a luxury they could not afford, and it is debatable whether they were informed at all that these institutions existed.

The main cause of death in patients of all ages covered by this research was tuberculosis of the lungs, and to a lesser extent heart failure, dysentery, typhoid, or they were dying from the effects of sexual diseases. Radoslav Lopašić, a psychiatrist from "Stenjevec", spoke about 
pletely mentally and physically dysfunctional. On the one hand, the cause of their decline in despair can be attributed to the symptoms of mental disorders, while on the other, as consequences of the burden resulting from institutional constraints. In 1939, Abraham Myerson, American psychiatrist, stated that the feeling of indifference in people with mental disorders was potentiated by their long-term isolation and segregation in psychiatric hospitals. The phenomenon of their phlegmatic and lethargic nature was later described as the "motivational vacuum" (Bennett 1988: 46-47). Almost three decades later, in 1966, Russell Barton, British psychiatrist, after years of considering catatonic stupor in long-term hospitalised patients with schizophrenia, developed a concept called "institutional neurosis". According to Barton, the features of this form of neurosis were the absence or diminished need for contact with the environment, loss of individuality and resigned acceptance of life circumstances. He argued that one of the key factors contributing to the development of the aforementioned psychiatric conditions is the long-term social exclusion of persons with mental disorders into psychiatric institutions (Barton 1966: 13-15). An example that could illustrate the phenomenon of "motivational vacuum" is the case of the patient who was forty-two years old married man. He was transferred from "Stenjevec" to "Pakrac" in 1921 and died of tuberculosis of lungs after three months. He was treated under the diagnosis of schizophrenia.

"He sits mostly in the living room with other patients, at times he just sat motionless staring in front of himself for hours. Sometimes he would get up again for a short while, straightened up and stood stiff for a moment, then fell back into place." (Male patient files, Pakrac, September 1921)

From the patient files of the soldiers treated in "Stenjevec" and "Pakrac", no notes were found confirming that they were engaged in any form of therapeutic activity, especially not in agricultural works. Performing work on hospital properties required the involvement of patients of greater physical fitness and mental endurance, so it is understandable that physically exhausted and emotionally distracted soldiers were not used as a workforce. The following quote is just one of many examples that clearly illustrates the consequences of Croatian soldiers' suffering on the front lines in the WWI. Its contents describe the experience of a twenty-five-year-old patient who was treated in 1920 for a schizophrenie catatonia in "Stenjevec". After half a year at the hospital, he died of lung tuberculosis. Records from his patient file do not confirm that he was married and had children.

"He stares lifelessly, mistrustfully. Three years in war already, always Galicia. Wounded in the head by a grenade, he barely knew anything for eight days. He had a great gash on the left side of his occipital bone (...). Mayor of the municipal government asks the institute to let the patient, an only son who has been in the war since its very beginning and who is now recovering in Zagreb, return home to his parents who do not have anyone else to help them." (Male patient files, Vrapče, April 1920)

The previous content not only outlines the state of this soldier's internal deadness and sense of loss but also reveals a lack of understanding of the environment for his physical weakness and psychological trauma. The lack of empathy for the mentally ill soldiers is, in a sense, not surprising, since those who did not directly participate in the war were equally physically and emotionally drained. Due to malnutrition and strenuous agricultural work, the rural population often became infected by Spanish flu and other infectious diseases (Kolar-Dimitrijević 2011: 98). Women were forced to take on jobs that were 
otherwise performed by men, so they were doubly physically and mentally burdened, and thus more susceptible to becoming ill. In one word, civilians had their private war on the "home front" (Hunt 2017: 150).

The life of rural populations in continental Croatia in the interwar period, the residence of the majority of patients treated in "Stenjevec" and "Pakrac", was permeated by "hard and constant work, and with almost no knowledge of leisure time" (Leček 1997: 216). On the one hand, experts did not know the epidemiology of mental disorders of traumatised soldiers nor the right methods of their treatment. It is therefore difficult to expect that the rest of the rural environment, which had little or no educational status, could understand the complexity of the effects of traumatic war events on the emotional and social functioning of war veterans with mental disorders. On the other hand, psychiatric treatment was often not available to many of them, which further contributed to the unfavourable outcome of their mental illness caused by war trauma.

\section{Limitations of Psychiatric and Social Care for War Veterans with Mental Disorders}

One of the fundamental features of WWI warfare was artillery shelling and gas attack on soldiers in trenches and fortifications. The soldiers died most of the consequences of explosive grenades, gas poisoning and physical illness. However, they did not suffer only from physical diseases, but also from mental disorders. Considering that the appearance of "war neurosis" with soldiers was most often associated with exposure to grenade explosions, British psychologist Charles Samuel Myers named this form of mental disorder "shell shock". "Shell shock" was mentioned for the first time in the medical journal The Lancet in February 1915. Afterwards, as Myers himself points out in his diary entries from the French battlefield, that concept was a needless innovation because of the complexity and diversity of the difficulties that caused soldiers' mental disorders (Myers 1940: 37). The peculiarity of the "shell shock" concept was that it could not be translated into other languages and that it did not carry within elements that suggested the dramatic psychological consequences of the war. In some ways, it had a protective effect on the development of stigmatisation and social exclusion of the soldiers with mental disorders and their families (Winter 2000: 9-10).

the difference between the approach to treating tuberculosis in our psychiatric hospitals and its treating in Germany. He was pleasantly surprised by the "villa with a beautiful and colorful garden and park around" built separately from the psychiatric hospital and used to house patients with tuberculosis. $\mathrm{He}$ compared it with a certain dose of discomfort to "infectious huts of our one hospital, which has these special qualities, that it is cold in it in winter and heat in summer". Lopašić indicated "that in these villas psychiatric patients are treated by psychiatrists with special training in tuberculosis". As an extremely positive feature of the tuberculosis treatment strategy in German psychiatry, the latter emphasized the isolation of patients from the ward into the aforementioned villa when the first symptoms of lung infection appeared. Following this experience, he concluded that for a significantly lower percentage of tuberculosis mortality in German "hospitals" compared to our meritorious early intervention and the separation of diseased patients into separate facilities ensuring adequate hygiene conditions (Lopašić 1924: 32-33).

9

"Shell shock" was the forerunner of today's posttraumatic stress disorder diagnosis. PTSD was introduced in 1980. The American Psychiatric Association added PTSD in the 3rd edition of the Diagnostic and Statistical Manual of Mental Disorders. That act was brought to them by the experience of the Vietnam War (Crocq, Crocq 2000: 52-53). 
In this research, the cases of "shell shock" were not identified. Patients who were identified with symptoms of a psychiatric illness that were possibly caused by their participation in the battlefield were diagnosed with schizophrenia, dementia secundaria, dementia paralytica progressiva or hebefrenia. In this sense, it is important to note that by attributing psychiatric diagnoses, the process of stigmatising the patient begins. Whether or not they accept the labels imposed on them by the environment, negative attitudes and prejudices about their illness will likely lead to the creation of low self-esteem and the need to separate from the community in which they are stigmatised (Corrigan, Watson 2002: 16-17). The consequences of negative labelling are evidenced in the case of a patient who was treated in a psychiatric ward at Pakrac Hospital in 1921. Until he was mobilised to war, he worked as a blacksmith in a village in Slavonia. He was married, but it was not recorded whether he had children. He died at the age of twenty-eight after almost five months of treatment with dementia paralytica progressiva.

"He was captured in the army, later in 1916 joined the Legion. He was not injured. He was now at home, where he didn't work anything. The moral and ethical feeling is very emphasised, intelligence suits his peasant status. He asks for help, to get out from hospital as soon as possible because he wants to work. He just does not want to go back to his village where they know his illness." (Male patient files, Pakrac, May 1921)

Since traditional archetypal characteristics of soldiers include heroism, strength, and psychophysical endurance, soldiers who lost these virtues because of traumatic experiences were often degraded and labelled as a weak and cowards (Op den Velde 1998: 13). Given that, in the context of patriarchy, strength and physical superiority presuppose the prestigious qualities of men, and that the studied population has lost these indicators of masculinity after returning from the battlefield, they became a threat, but also a burden to the community. Although some of them were ill before mobilisation, however, this circumstance was not taken into account. Quote from the patient file of a twenty-five-year-old man from "Stenjevec" clearly demonstrates a misunderstanding of the environment for his psychic condition war and post-war traumatic experience. The patient came from a village in northwestern Croatia, where he worked on his parents' farm property before the war began. $\mathrm{He}$ never married or had children. He died in "Stenjevec" in 1921, allegedly from a heart attack after less than three months of hospitalisation. He was treated under the diagnosis of mania.

"He had suffered several years before he arrived here. He served three years in the military as a trench fighter. At the end of the war, he was buried in dirt due to a grenade explosion in his immediate vicinity, so that only his hands were sticking out of the ground. Afterwards he fell into slavery with the Italians, where he first had to lie in a hospital after which he had to work in the field lest he should be beaten. Says he has suffered from epilepsy since his early childhood. He had it also as a soldier but nobody cared about it and he had to serve nonetheless." (Vrapče, Male patient files, March 1921)

If the men avoided going to the military, they were sanctioned. In other words, they were sanctioned if they would resist the patriarchal rules of masculinity. They were formally punished, criticised and exposed to shame. In considering the concept of shame, it is often said that this feeling arises when social and moral perceptions of the individual that have already been built up in public begin to collapse. Culturally speaking, the imperatives of patriarchy consist precisely in the constant insistence on male perfectionism, which is opposed to the concept of shame. Bearing in mind that shaming and ridicule are the way to discover weakness and weaklings are not popular in male culture, soldiers with mental 
disorders have been forced to accumulate frustrations that were very possibly were one of the causes of their (self)aggression (Stuewig et al. 2009: 2).

Although psychiatric hospitals were established even before, the need for organised psychiatric service in the military first appeared during WWI (Hudolin 1981: 360). At that time, psychiatry and psychology were only trying to establish themselves as new scientific and professional disciplines. It is logical, therefore, that soldiers and war victims mostly turned to doctors for physical disabilities, although they were essentially mentally ill. According to Serbian psychiatrist Jovan Ristić, the mental state of the psychiatric patients at the time was not associated with the external circumstances.

"Left to himself, the man, when mentally ill, had to find the cause of this disorder in himself, in his wicked inner structure." (Ristić 1979: 14-15)

\section{British psychiatrist Guy Goodwin describes the history of psychiatry as}

“... the history of how doctors came to see abnormal or extreme beliefs, emotions, and behaviour as a form of illness and created a medical specialty to formalise the approach to people presenting with such problems."

When a physical health problem occurs, it is understandable that because of the biological markers on which the diagnosis is made, doctors have a sense of understanding what disease they are treating, and it is clearer to patients what they are suffering from (Goodwin 2017: 2-3).

Although in the early post-WWI, the systemic care for the war invalids was underdeveloped, the health and social care system tried to provide institutional assistance for veterans with physical disabilities. For example, at the end of 1919 at the Erdody's castle in Popovača, ${ }^{10}$ Ministry of Social Policy and Public Health of the Kingdom of SCS opened institution for the disabled called "Moslavina". Its purpose was the subsequent treatment and re-education of disabled war veterans. ${ }^{11}$ Besides that, in 1915, initiatives were launched to help soldiers with disabilities to find new jobs, special schools were opened to retrain those who were no longer able to work because of physical injuries which they did before the war etc. In other words, the system took care of the resocialisation of soldiers with physical disabilities, while those with mental disorders were exclusively offered treatment in psychiatric hospitals (Liječnički vijesnik 1915: 127-129). Austrian neurologist Sigmund Freud stated in 1920 that "all war neuroses are a subconscious escape to disease from war conditions and that with the end of the war they will fade away because their psychological cause will disappear" (Op den Velde 1998: 15). ${ }^{12}$ It is therefore not surprising that the level of knowledge and understanding for war veterans with mental disorders in this region, in which the number of doctors and the educated population was generally significantly lower than in Austria, was minimal or completely absent. ${ }^{13}$

10

Today known as Neuropsychiatric Hospital Dr. Ivan Barbot Popovača.

11

HR-DASK-161-Popovača Mental Illness Hospital, Hospital inventory report, during 1940.

12

Only later, Freud, like many other experts, found that psychological traumas caused by war circumstances did not end spontaneously after the war ended (Eissler according to Op den Velde 1988: 15).

13

Speaking of elementary education in Croatia in the interwar period, it is certain that "schools did not open even where it was prescribed, and the existing ones did not expand", thus, in some regions recorded was seventy-five percent of 


\section{Changes in Family Dynamics in the Post-war Years}

The traditional family, as opposed to the modern family, which promotes the freedom of its members in most aspects of their lives, is a system within which the boundaries and spaces of its members are clearly regulated. To maintain a stable familial structure, the rules that apply to their roles must be respected (Dagenais 2009: 4-5). Attitudes and behaviours related to gender roles are shaped following the biological predispositions of the individual and the cultural and social imperatives about the (un)acceptable femininity and masculinity recognised in their home community. The relationships and position of family members largely depend on the extent to which they (do not) fulfil the tasks assigned to them by their gender role (Marks, Chun Bun, McHale 2009: 12-13). This paper focuses mainly on the traditional nuclear family because the population covered by this research came from such structured communities. It is well known that within the patriarchy a man is at the highest level of the family hierarchy, he is the breadwinner and protector of the family and makes decisions about the child's future (Erlich-Stein 1971: 61). However, after the return of soldiers with mental disorders from the battlefield, their de-hierarchy within the earlier family structures occurred because they no longer showed the ability, willingness and need to perform tasks related to their gender role. Consequently, the redefinition of the family status of the latter, that is, their interiorisation by the immediate and wider environment, as well as self-marginalising, put them in a position of powerlessness. From a gender perspective, seeking to re-establish power and control within the family, the mentally ill soldiers used physical strength and threats. In this analysis, one must certainly not forget the psychological and psychiatric aspect of their aggression and violence, that is, the fact that they were a population with clear mental illnesses.

The occurrence and development of violent behaviour in patients with mental disorders are influenced by a number of biological, psychological and sociological factors (Rueve, Welton 2008: 37). Their propensity for violence can be linked with "psychopathological symptoms such as delusions or hallucinations, comorbid substance use, social deterioration, or other clinical symptoms" (Soyka 2011: 913). The type and intensity of expression of aggression in psychiatric patients also depend on their subjective experience of a frustrating situation (Varshney et al. 2016: 223-225). According to the psychodynamic theory, "aggression is a mental phenomenon that is expressed in interpersonal relationships, and the response to inadequate external and internal excessive constraints or lack of control in achieving pleasure" (Jukić, Savić 2014: 104) should be singled out. This thesis is significant because the causes of aggression and domestic violence of war veterans with mental disorders could be partly explained by the fact that the domestic violence was limited by external (difficult economic situation, infectious diseases) and internal circumstances (depersonalisation, derealisation) and due to their inability to establish formerly, presumably, satisfactory family status, they were aggressing and violent against members of the immediate and broader environment. One of the ways in which they manifested their aggression was physical violence. The mentioned phenomenon is well described in the quote below that was found during the analysis of the patient file of a thirty-year-old farmer from a village in the Banovina area. He was treated for three months during 1920 in "Stenjevac" under the diagnosis of mania. He died at the hospital from pulmonary tuberculosis. 
"Way of life: until being recruited, he was always quiet, having good manners and living in harmony with his wife and parents.

Significant events for his mental health: recruited in 1915 and left the service after only a month. What the custodians and neighbours say about him: after leaving the service, he immediately fell ill, possibly due to immense fear. Assaults people on the road. After a month, he rushed on his mother's brother with a knife. The wife has left with the children and the mother dares not remain with him in the house during the night. Deranged in a high degree already." (Male patient files, Vrapče, May 1920)

Their aggression was primarily targeted at wives and children, but that the victims of their violence were also members of the wider family and neighbours. The violence involved the use of physical force and psychological violence. No notes on sexual violence have been encountered so far, however, that does not mean that it did not exist; rather, it means that it was not recorded. ${ }^{14}$ Speaking of sexuality was generally a taboo. The first demographics and psychiatrists in the nineteenth century, for example, would offer an apology to the readers when mentioned sex, keeping their attention on such antagonistic content. Therefore, it would not be surprising that if there were any cases of sexual violence that they would not report it, probably because of the shame ([Fukooucault] 1978: 11). Moreover, the question is whether the victims of sexual violence from the beginning of the 20th century were able to recognise that they had been abused. Some sexual behaviour which are known today as not acceptable and that leave profound negative consequences on the victim's emotional life were not perceived as risky during that period (Latchana Kenney 2012: 16-17).

Apart from physical and psychological violence, it was apparent from this research that mentally ill war veterans were conducting economic family violence. Economic violence, in addition to the prohibition on disposing of personal income, the ban on employment, etc., involves the destruction of personal and collective property (Fawole 2008: 2-3). Judging by the fact that the non-mobilised family members managed to maintain their households and agricultural holdings on their own, it is difficult to conclude that they were existentially dependent on mentally ill war veterans. This is to say that one of the reasons why most of them tried to maintain a stable family structure, despite the various forms of (self)destructive behaviour of the latter, was probably because the then-rural population in continental Croatia was mostly Christian-oriented. ${ }^{15}$ From the point of view of Christianity, in the relationship between the spouses - bearers of the family - "there may be heights and recesses", but with their mutual tolerance, crises can be overcome. Moreover, crises can help them "become more resilient and firm" (Lasić 1988: 326). ${ }^{16}$ However, the concept of tolerance can be interpreted in two ways, and thus, in some discussions on the same topic, it is stated that "tolerant" is the posi-

the illiterate population. In addition, due to the lack of teachers, teaching in primary schools was often led by non-professional staff (Čajkovac according to Miljković 2007: 136).

14

It is important to note that this research only covered the patient files of men. The question is whether in the personal documentation of female patients treated in "Stenjevec" and "Pakrac" were recorded cases of sexual violence against them by war veterans with mental disorders.
15

One of the data that was recorded in patients' generals was their religious affiliation. This research showed that patients were mostly Catholics and Orthodox, and very rarely Jewish and Muslims.

16

The Catholic theorist of tolerance, St. Augustine, preached "that one must necessarily live together with evil because it is impossible to remove it" (Trimarchi, Papeschi 1996: 322). 
tion of a person who, usually because of 'force majeure' (...) allows others to believe and allows others to behave differently, or just the opposite of her own principles, ideas, or desires" (Trimarchi, Papeschi 1996: 322). According to the second thesis, tolerance does not have as much to do with understanding and accepting the views and behaviour of the other as it has to do with their submitting because of determined circumstances. Despite the efforts to endure the asocial behaviours of war veterans with mental disorders and prevent later possible stigmatisation, their families were still compelled to seek hospitalisation in psychiatric institutions in some cases. This can be read from the following case concerning a twenty-eight-year-old soldier from a village in Slavonia. The patient was a blacksmith by profession. He was married, a father of two children. In "Stenjevac" he was treated for almost five months during 1919 under the diagnosis of dementia paralytica progressiva. He died at the hospital from heart failure.

\footnotetext{
"Way of life: after returning from the military hospital, has not been doing anything for eleven months.

Particular habits: sits the entire day, talks little.

Passions and vices: when he gets mad, he wants to fight

Significant events for his mental health: nothing could be observed about him before the war, in the third year of the war he returned home barefoot, naked and hatless.

What the custodians and neighbours say: when he gets upset, which occurs often, he wishes to beat anyone he gets his hand on, even cattle. Yet when he is yelled at, he stops and calms down and speaks unintelligibly." (Male patient files, Vrapče, June 1919)
}

On the one hand, war veterans with mental disorders did not know how to adequately, in a way that would not endanger others, express their feelings. On the other hand, their family members did not know how to handle their aggression, so they returned them to the same measure. The above-cited quotation also shows that verbal aggression, or more precisely, the shouting of the custodians and neighbours to those who behaved violently, was a method used to suppress their destructive behaviours. This case illustrates only one form of domestic violence. During this research, numerous examples showed that perpetrators of domestic violence were in some cases family members who did not directly participate in the war and that their verbal attacks on mentally ill war veterans sometimes turned into their physical abusing. An additional difficulty was that there was no time and space for trauma in the family environment because life in the village moved around exhausting allday work, which was also the most common and certainly the most important theme of the conversation. Writing about rural family in this period, Croatian historian Suzana Leček pointed out that "when it was discussed, it was never about personal feelings or desires, but about real, external problems that pertained to the household" (Leček 2003: 387-388). When interpreting traumatic experiences and how the locals dealt with them, the temporal context should be taken into account. Specifically, post-war psychiatry in the 1920s did not know the psychosocial approach to trauma treatment. ${ }^{17}$ During this period, the medical model of treatment dominated, focusing on the physical health of the traumatised person rather than the psychic. Until the 1980s, that is, sixty years later, psychosocial approach in the treatment of persons who have experienced some form of trauma, it is officially recognised as legitimate (Kraljević, Bunjevac 2009: 138). It is therefore not surprising that the post-war rural population in continental Croatia did not know how to provide adequate psychosocial assistance to a mentally traumatised soldier after they returned home from the battlefield. 
The pattern of behaviour of mentally ill soldiers, often cited in the analysed patient files, was the lack of their interest in everyday activities. Loss of interest in activities that were once important to them and feelings of alienation and hopelessness were indicators of depression. Depressive disorder often occurs in people with PTSD. Patients with this comorbidity may experience significantly more severe symptoms of both disorders and changes in mental function and behaviour, compared with the population with isolated PTSD or depression. Finally, low or no motivation for life and loss of expectations for the future, symptoms inherent in both disorders, can often lead to an increase in suicidal risk (Armenta et al. 2018: 4; Stevens et al. 2013: 2-3).

Inability to realise the role of a family breadwinner, viewed from a gender perspective, puts men in a more dependent position regarding women. The passive position in traditional societies continues to create a sense of humility in many men today, which may cause difficulties in establishing relationships with the rest of the community. It is thought that the loss of a dominant position of a man in the family and the wider environment can potentially lead to frustration and lead them to exhibit internalised and externalised behaviours. An additional difficulty is that in patriarchy, male subordination is mostly viewed with derision (Robertson 2018: 1125-1126), and it is not uncommon for the latter to accept negative prejudices and stereotypes about their masculinity themselves.

Talking about the post-war everyday life of war veterans with mental disorders, whose experiences are discussed in this paper, it can be stated that they were mostly not supported by external factors (family and the wider community), nor were they able to use their internal mechanisms (self-esteem and self-understanding) as self-support in the process of resocialisation. The following case is not the only one, in fact, there are numerous examples encountered during this research that show difficulties in integrating of the study population into the community of in the post-war years, but this was considered to be representative enough to illustrate this phenomenon. The following quote is significant also because it clearly shows the patient's struggle with guilt and shame about participating in military operations. The quote is taken from the patient file of a forty-year-old farmer from a village in Slavonia. The patient was married but had no children. He was hospitalised in "Pakrac" for a month in 1921 where he was diagnosed with melancholia. After a month of treatment, he was discharged from the hospital allegedly cured.

"He was telling his family that when he was at war, he hid a lot of things in the war, that's why God abandoned him (...). Yesterday, he hit the ax with a blade several times in the head using the opportunity when his wife was away from him for an instant and he went to the chamber after the ax (...). Since he is ill he is not engaged in any business, but goes away oversees how others work." (Male patient files, Pakrac, May 1921)

However, in addition to behavioural changes, specifically autoaggressions, caused by a strong sense of inadequacy and inferiority, the previous quote shows the inability of the patient to assume work-related responsibilities. But,

17

Psychosocial interventions include helping to address the basic existential needs of the traumatized person, assisting in their psychosocial functioning in the immediate and broader community, working to stabilize family dynamics through psychotherapy treatments and providing legal counseling. A prerequisite for the adequate provision of psychosocial assistance is the first identification of the key existential, emotional and social priorities of a person who has experienced a traumatic experience (Kraljević, Bunjevac 2009: 138) 
war veterans with mental disorders were not only emotionally unstable and socially disoriented; they were also physically exhausted. Therefore, most of the time, they were neither able to go to work in fields that were often quite far from peasant houses, nor to take care of livestock and cultivate the land, participate in sowing and harvesting (Šimončić-Bobetko 1994: 148). As previously stated in the $1920 \mathrm{~s}$, the community and society did not have sufficient hearing for the emotional distress and social maladjustment of mentally ill war veterans due to their ignorance and misunderstanding. Recent insights into the approach to treating PTSD point out that "for many patients, the new traumas they encounter in their environment and social disappointments contribute to deepening the trauma of war" (Keane et al. according to Ćurković 2009: 226). In considering the consequences of (un)success in achieving gender-based expectations on self-esteem, the question arises to what extent the lack of support for the environment contributed to the development of a negative self-image in the study population. Considering that due to the nature of their illness, the latter did not fully or absolutely satisfy the patriarchal stereotypes of masculinity, it raises the question of whether and in what way this circumstance further impeded their social exclusion and intensified their feeling of powerlessness.

In addition to finding that most war veterans with mental disorders did not fulfil their breadwinner roles after returning from the battlefield, it was also evident that they were often unable to fulfil the requirements of a paternal role. The following example refers to the impact of the absence of a father during the war on the upbringing process of a male adolescent who was hospitalised in psychiatry. This does not imply that the exclusion of the father from the rearing of the girls left no mark on the formation of their system of values and behaviour, but that no such case was recorded within the collected corpus of the archival material.

Bearing in mind that in the patriarchal system boys are obliged to listen to adult men (Spajić-Vrkaš 1995: 452-453), and that they represent the basis on which they build their manhood, it is not surprising that the absence of a paternal figure, traditionally attributed to austerity and consistency, can cause problems in raising of some male children. In this regard, it should be noted that difficulties in the socialisation of adolescents often adversely affect the overall balance of their families, especially those of the poor with more members (Siegel et al. 2013: 3). Today juvenile offenders are being taken to correctional facilities, but since there were no such institutions in Croatia at the beginning of the 20th century, the latter were hospitalised in psychiatric hospitals. This phenomenon confirms the case of a seventeen-year-old patient from "Stenjevec". The young man was educated for the profession of butcher. He was originally from a village in the Zagorje region. After nearly a year of psychiatric treatment during 1919 under a diagnosis of hebephrenia, his mother took him home allegedly healthy.

"The way of life was exemplary in childhood; the child was raised well. When his father was called to the military two years ago, remained examined in the hands of his mother, who could not strictly pay attention to him, so he began to spend time with his companions in the taverns, arriving home late at night, and leading a messy life at all. He would often come home drunk and then, in a drunken state, would be aggressive (...). Institution internment is necessary because he is very restless and his father is in the military his mother is not able to manage this situation alone and the house is full of young children. Property circumstances are very weak." (Male patient files, February 1919) 
On the one hand, the temporary absence of the physical and emotional presence of the father in the educational process, as already mentioned, can leave negative consequences on the formation of the personality and social relations of the boy. On the other hand, the subsequent involvement of the father in the upbringing of children in general can result in the father becoming an instrumental educator, more precisely a secondary object in the child's life (McLanahan, Tach, Sneider 2014: 17-18). Many men who returned from the WWI due to various forms of mental illness and physical disability were unable to become actively involved in the upbringing of their children and were therefore given the status of an instrumental educator. Also, due to poverty, especially of the rural population, the primary goal of the post-war generation of fathers was to ensure personal and family existence, while establishing emotional closeness with their children was mostly secondary to them (Leček 1997: 234). Due to personal health difficulties (mental and physical), war veterans with mental disorders mostly failed, both in taking on responsibilities related to feeding the family and in providing moral and emotional support to their children. Therefore, the question of the long-term consequences for the development of emotional and social skills, the generation of children whose fathers participated in the WWI, remains open. To properly consider the transgenerational transmission of trauma from Croatian war veterans with mental disorders from WWI to the social integration of their offspring, future research should focus on the analysis of the post-war everyday life of their children.

\section{Conclusion}

Methods of treatment of war veterans with mental disorders in Croatian psychiatric hospitals in the 1920s followed the trends in the profession to some extent. However, during the work organised as part of occupational therapy, one of the then-key forms of psychosocial rehabilitation of psychiatric patients, hospitalised soldiers could not participate due to the severe consequences of traumatic war experiences on their physical, mental and social condition. Therefore, both in the home community and psychiatric hospitals, the process of their social inclusion was complicated. On the one hand, difficulties in the resocialisation of war veterans with mental disorders were caused mainly by ignorance and non-recognition of the severity of mental illnesses by the medical profession. On the other hand, the process of their reintegration into the community was hampered by ignorance and lack of sensibility of the immediate and wider environment for significant changes in their mental state that were the result of war trauma. Admittedly, difficulties in the social inclusion of war veterans with mental disorders were created by their inability to process their own traumatic experience. From this research, it was evident that they were often prone to aggressive outbursts directed at their family members and neighbours, as well as other antisocial behaviours, such as theft, vagrancy, excessive alcohol consumption, etc.

Given that most mentally ill war veterans were no longer able to work in agriculture, which was the main occupation of the rural population in rural areas of continental Croatia in the 20s of the 20th century, they lost their role of breadwinner of the family. Furthermore, speaking about the realisation of their parental role, the fact is that in this respect the latter were mostly unsuccessful, both due to physical inaccessibility and due to emotional distancing 
caused by the symptoms of mental illness. Because due to the nature of their illness, war veterans with mental disorders did not fully or absolutely meet the social roles intended for men, they were stigmatised in their environment. In addition, due to the impossibility of self-actualisation within the desirable patterns of the patriarchal system, they gradually internalised the stigma, that is, they self-stigmatised, which ultimately deepened their sense of non-belonging.

\section{Archival sources}

Male patient files: 1919-1924, Archives of the Clinic for Psychiatry Vrapče, Zagreb 19191924.

Male patient files: 1919-1924, Museum of the City of Pakrac, Pakrac 1919-1924.

State Archive Sisak, HR-DASK-161-Popovača Mental Illness Hospital, Sisak 1940.

"Care for the War Veterans", Liječnički vijesnik 37 (1915) 6, pp. 127-129. Available at: https://library.foi.hr/m3/casview.aspx?sql=SDCCDCYC9C5YDDDD6-DDD-SSDC27 (accessed on 3 April 2020).

\section{References}

Armenta et al. (2018): "Factors associated with persistent posttraumatic stress disorder among U.S. military service members and veterans", BMC Psychiatry 18 (2018) 48, pp. 1-11, doi: https://doi.org/10.1186/s12888-018-1590-5.

Barton, R. (1966): Institutional Neurosis, John Wright and Sons Ltd., Bristol.

Bennett, D. H. (1988): "Psychosocial Rehabilitation: Evolution, Principles, and Application in Combating Negative Symptoms", International Journal of Mental Health 16 (1988) 4, pp. 46-59, doi: https://doi.org/10.1080/00207411.1987.11449075.

Berglas, B. (1933): “Terapija radom u našoj bolnici”, in: Niketić, B.; Župić, S. (eds.), Stenjevec državna bolnica za duševne bolesti 1879. - 1933. Spomenica povodom pet decenika rada, Društvo za socijalnu pomoć duševnim bolesnicima u Stenjevcu, Zagreb, pp. 102-108.

Crocq, M-A.; Crocq, L. (2000): "From Shell Shock and War Neurosis to Posttraumatic Stress Disorder: a History of Psychotraumatology", Dialogues in Clinical Neuroscience 2 (2000) 1, pp. 47-55. Available at: https://www.ncbi.nlm.nih.gov/pmc/articles/ PMC3181586/ (accessed on 11 December 2020).

Dagenais, D. (2009): The (Un)Making of the Modern Family, UBC Press, Vancouver.

Corrigan, P. W.; Watson A. C. (2002): "Understanding the impact of stigma on people with mental illness", World Psychiatry 1 (2002) 1, pp. 16-20. Available at: https://www.ncbi. nlm.nih.gov/pmc/articles/PMC1489832/pdf/wpa010016.pdf (accessed on 9 April 2020).

Ćurković, J. (2009): “Identitet hrvatskog veterana u tjesnacu krivnje i bolnog sjećanja Interdisciplinarni pristup PTSP-u kao uvod u teološku raspravu", Bogoslovna smotra 79 (3009) 2, pp. 223-245

Fawole, O. I. (2008): "Economic Violence to Women and Girls: Is it Receiving the Necessary Attention?", Trauma, Violence \& Abuse 20 (2008) 10, pp. 1-11, doi: https://doi. org/10.1177/1524838008319255.

Erlich-Stein, V. (1971): Familiy in transition: A study in 300 hundred Yugoslav villages, Liber, Zagreb.

Fuko, M. [Foucault, M.] (1978): Istorija seksualnosti: Volja za znanjem, translated by Jelena Stakić, Prosveta, Beograd.

Frankl, V. E. (2014): The Will to Meaning: Foundations and Applications of Logotherapy, Penguin, New York. 
Goodwin, G. (2017): Psychiatry. Reference Module in Neuroscience and Biobehavioral Psychology, Elsevier Inc.

Herman Kaurić, V. (2014): “Kraljevska zemaljska bolnica u Pakracu-primjer gospodarskog poslovanja velike bolnice u velikom ratu”, Scrinia Slavonica 14 (2014) 1, pp. 193-216.

Herceg, R. (1933): “Zavod za umobolne 'Stenjevec' od 1879 do 1933”, in: Niketić, B.; Župić, S. (eds.), Stenjevec državna bolnica za duševne bolesti 1879. - 1933. Spomenica povodom pet decenika rada, Društvo za socijalnu pomoć duševnim bolesnicima u Stenjevcu, Zagreb, pp. 6-29.

Hudolin, V. (1981): Psihijatrija, Jugoslavenska medicinska naklada, Zagreb.

Hunt, K. (2017): "Gender and Everyday Life", in: Grayzel, S. R.; Proctor, T. M. (eds.), Gender and the Great War, Oxford University Press, Oxford, pp. 149-168.

Jukić, V.; Savić, A. (2014): "Psihološko-psihijatrijski aspekti nasilja", Socijalna psihijatrija 42 (2014) 2, pp. 102-108.

Kraljević, R.; Bunjevac, T. (2009): "Psihosocijalne intervencije kao oblik pomoći traumatiziranim osobama", Suvremena psihologija 12 (2009) 1, pp. 135-154.

Kolar-Dimitrijević, M. (2011): “Doprinos Podravine prehrani Hrvatske u Prvom svjetskom ratu", Podravina 10 (201) 19, pp. 97-118.

Kuti, S.; Gregurović, M.; Božić, S. (2011): “Ograničenja konceptualizacija rezidencijalne segregacije: povratak socijalnom prostoru?”, Socijalna ekologija 20 (2011) 3, pp. 315-334.

Lasić, S. (1988): “Kršćanska vizija obitelji danas”, Church in the World 23 (1988) 4, pp. 321-330.

Leček, S. (1997): "Nismo meli vremena za igrati se .... Djetinjstvo na selu (1918 - 1941)", Radovi: Zavod za hrvatsku povijest 30 (1997) 1, pp. 209-244.

Lopašić, R. (1924): “Položaj umobolničkog liječnika”, Liječnički vijesnik 46 (1924) 3, pp. $70-75$.

Lopašić, R. (1924): "Psihijatrijske impresije iz Njemačke", Liječnički vijesnik 46 (1924) 1, pp. 31-38.

Marks, J.; Chun Bun, L.; McHale, S. M. (2009): "Family Patterns of Gender Role Attitudes", Sex Roles 61 (2009) 3-4, pp. 221-234, doi: https://doi.org/10.1007/s11199009-9619-3.

McLanahan, S.; Tach, L.; Schneider, D. (2014): "The Causal Effects of Father Absence", Annual Review of Sociology 39 (2014), pp. 399-427, doi: https://doi.org/10.1146/annurevsoc-071312-145704.

Miljković, D. (2007): “Iz povijesti osnovne škole u Hrvatskoj u razdoblju od 1918. do 1941.", Odgojne znanosti 9 (2007) 1, pp. 135-150.

Myers, C. S. (1940): Shell Shock in France, 1914-18, CUP Archive.

Op den Velde, W. (1998): "Dugoročne reakcije veterana na ratna iskustva", translated by Ines Trkulja, Polemos 1 (1982) 2, pp. 13-23.

Pavičić, S. (1998): Hrvatska ratna $i$ vojna povijesti. Prvi svjetski rat, Nakladničko trgovačko društvo Mato Lovrak, Zagreb.

Pelegrina, H. (2004): "Phenomenology. Transphenomenological Perpectives in Psychopathology”, in: López-Ibor, J. J.; Cercós, C. L.; Masià, C. C. (eds.), Images in Spanish Psychiatry, Editorial Glosa, Barcelona, pp. 75-90.

Rašković, J. (1983): “Odjel za neurologiju i psihijatriju”, in: Merlak, I. (ed.), 100 godina šibenske bolnice, Medicinski centar, Šibenik.

Rissanen, A. (2018): "Treatment and Rehabilitation: Patients at Work in Finnish Mental Institutions", in: Tuomas, L. F.; Eilola, J.; Hokkanen, M. (eds.), Encountering Crises of the Mind, Leiden, Boston, pp. 196-221, doi: https://doi.org/10.1163/9789004308534_009.

Ristić, J. (1979): "Psychiatric - Yesterday, Today, Tomorrow", ENGRAMI, Journal of Clinical Psychiatry, Psychology and Border Disciplines 1 (1979) 1, pp. 13-17. 
Robertson, L. H. (2018): "Male Stigma: Emotional and Behavioural Effects of a Negative Social Identity on a Group of Canadian Men", American Journal of Men's Health 12 (2018) 4, pp. 1118-1130, doi: https://doi.org/10.1177/1557988318763661.

Roelcke, V. (2005): "Continuities or Ruptures? Concepts, Institutions and Contexts of Twentieth-Century German Psychiatry and Mental Health", in: Gijswijt-Hofstra, M. et al. (eds.), Psychiatric Cultures Compared. Psychiatry and Mental Health Care in the Twentieth Century: Comparisons and Approaches, Amsterdam University Press, Amsterdam, pp. 162-182.

Rossler, W. (2016): "The Stigma of Mental Disorders. A Millenia- Long History of Social Exclusion and Prejudices", EMBO Reports 17 (2016) 9, pp. 1250-1253, doi: https://doi. org/10.15252/embr.201643041.

Rueve, M. E.; Welton, R. S. (2008): "Violence and Mental Illness", Psychiatry (Edgmont) 5 (2008) 5, pp. 34-38. Available at: https://www.ncbi.nlm.nih.gov/pmc/articles/ PMC2686644/pdf/PE 5 5 34.pdf (accessed on 21 August 2020).

Siegel, L. J.; Welsh, B. C. (2013): Juvenile Delinquency: The Core, Cengage Learning, Boston.

Spajić-Vrkaš, V. (1995): “Tradicija i vertikalna klasifikacija obiteljskih odnosa”, Društvena istraživanja 4 (1995) 4-5, pp. 451-464.

Soyka, M.; Meiringen, P. (2011): "Neurobiology of Aggression and Violence in Schizophrenia", Schizophrenia Bulletin 37 (2011) 5, pp. 913-920, doi: https://doi. org/10.1093/schbul/sbr103.

Stevens, D. et al. (2018): "Posttraumatic Stress Disorder Increases Risk for Suicide Attempt in Adults with Reccurrent Major Depression", Depression and Anxiety 30 (2018) 10, pp. 1-11, doi: https://doi.org/10.1002/da.22160.

Stuewig, J. et al. (2010): "Shaming, Blaming, and Maiming: Functional Links Among the Moral Emotions, Externalization of Blame, and Aggression", Journal of Research in Personality 44 (2010) 1, pp. 91-102, doi: https://doi.org/10.1016/j.jrp.2009.12.005.

Šimončić-Bobetko, Z. (1994): "Selo u Hrvatskoj 1918.-1934. - gospodarski aspekt", Povijesni prilozi 13 (1994) 13, pp. 139-178.

Trimarchi, M.; Papeschi, L. L. (1996): “Od tolerancije do prihvaćanja različitosti”, Društvena istraživanja 5 (1996) 2, pp. 321-329.

Varshney, M. et al. (2016): "Violence and mental illness: what is the true story?", Journal of Epidemiology and Community Health 70 (2016) 3, pp. 223-225, doi: https://doi. org/10.1136/jech-2015-205546.

Winter, J. (2000): "Shell-Shock and the Cultural History of the Great War", Journal of Contemporary History 35 (2000) 1, pp. 7-11. 


\title{
Jelena Seferović \\ Promišljanje (ne)moći muškaraca u kontekstu poslijeratne svakodnevice hrvatskih ratnih veterana $s$ psihičkim smetnjama iz Prvog svjetskog rata
}

\begin{abstract}
Sažetak
$U$ radu se raspravlja o resocijalizaciji hrvatskih branitelja s psihičkim smetnjama iz Prvog svjetskog rata. Analiza se temelji na istraživanju psihijatrijskih povijesti bolesti vojnika koji su se liječili u dvije hrvatske psihijatrijske bolnice od 1919. do 1924. godine. Proces njihove socijalne reintegracije $u$ zajednicu nakon povratka s ratišta razmatra se u odnosu na njihovu nemogućnost ispunjavanja normativnih očekivanja vezanih za rodnu uloge muškaraca. Namjera je bila istražiti je li ta okolnost dijelom pridonijela razvoju osjećaja nemoći kod veterana te posljedično uzrokovala njihova asocijalna ponašanja zbog kojih su bili socijalno isključivani iz svoje matične zajednice.
\end{abstract}

\section{Ključne riječi}

Prvi svjetski rat, ratni veterani s psihičkim smetnjama, resocijalizacija, rodne uloge muškaraca, nemoć, povijest psihijatrije

\section{Jelena Seferović}

\section{Reflexionen über die (Ohn-)Macht der Männer im Kontext des Nachkriegsalltags kroatischer Kriegsveteranen mit psychischen Störungen aus dem Ersten Weltkrieg}

\begin{abstract}
Zusammenfassung
In der Abhandlung wird die Resozialisierung kroatischer Verteidiger mit psychischen Störungen aus dem Ersten Weltkrieg erörtert. Die Analyse stützt sich auf eine Studie zu den psychiatrischen Krankengeschichten von Soldaten, die von 1919 bis 1924 in zwei kroatischen psychiatrischen Krankenhäusern behandelt wurden. Der Prozess ihrer sozialen Wiedereingliederung in die Gemeinschaft nach der Rückkehr vom Kriegsschauplatz wird im Zusammenhang mit ihrem Unvermögen betrachtet, normative Erwartungen bezüglich der Genderrollen der Männer einzulösen. Die Intention war zu untersuchen, ob dieser Begleitumstand teilweise zur Entwicklung von Ohnmachtsgefühlen bei Letzteren beitrug und mithin deren asoziales Verhalten verursachte, aufgrund dessen sie sozial von ihrer Heimatgemeinschaft ausgeschlossen wurden.
\end{abstract}

\section{Schlüsselwörter}

Erster Weltkrieg, Kriegsveteranen mit psychischen Störungen, Resozialisierung, Genderrollen der Männer, Ohnmacht, Geschichte der Psychiatrie 


\section{Jelena Seferović}

\section{Réflexions sur la (non) puissance des hommes dans le contexte du quotidien de l'après-guerre des vétérans croates sujets à des troubles psychiques suite à la Première Guerre mondiale}

\section{Résumé}

Ce travail discute de la resocialisation des vétérans croates ayant des troubles psychologiques suite à la Première Guerre mondiale. L'analyse se fonde sur la recherche des dossiers médicaux de soldats pris en charge par deux hôpitaux psychiatriques croates de 1919 à 1920. Le processus de leur réintégration sociale au sein de la communauté, suite à leur retour du champ de bataille, est examiné en relation avec leur impossibilité à combler les attentes liées aux rôles de genre attribués aux hommes. L'intention est d'examiner dans quelle mesure cet environnement a partiellement contribué à créer un sentiment de non puissance chez ces derniers, et est, par conséquent, en cause du comportement asocial en raison duquel ils ont été exclus socialement de leur communauté d'origine.

\section{Mots-clés}

Première Guerre mondiale, vétérans de guerre avec troubles psychiques, resocialisation, rôles de genre attribués aux hommes, impuissance, histoire de la psychiatrie 